\title{
TIME Model for Design Research
}

\author{
Luz Del Carmen Vilchis Esquivel \\ National Autonomous University of Mexico (UNAM)
}

The TIME model has been developed based on the understanding of the causes that prevent the completion of design research projects. The topic encompasses the constructs of orientation and education, where scientism in teaching and design research leads to multiple methodological problems both in theorizing and in professional practice. It is not overlooked that it is the reason for numerous dropouts from graduate studies or research systems due to the implementation of the scientific method model. The most concerning impacts of this vision are the low rate of graduation and peer-reviewed publications in the field of Design. The objective of this text is to present the TIME model as an original and innovative alternative for teaching research considering the objectivity, subjectivity and intersubjectivity of Design. The postulation of the method has been based on the principles of Hegelian dialectics and hermeneutics. This model has been applied in different contexts as a pilot experience and then in a permanent practice until consolidating it as part of the research methodology in Design.

Keywords: methodology, research, pedagogy, model, dialectic

\section{INTRODUCTION}

Time is a word that in Spanish comes from the Latin tempus meaning the possibility of naming sequences of events attributing to them a duration based on the second, an international unit based on which human beings refer to the past, present and future. Time delimits seasons, years, epochs, climate, among other things.

In English the word "Time" is a term that acts as a noun referring to the indefinite and continuous existence and past, present or future events. It is also a verb that includes planning, scheduling or organizing what is to be done. Among the multiple synonyms are: to project, systematize, arrange, configure, set lapses, structure, calendarize or schematize. Indistinctly it can mention the action or the person who performs it. "Timing" describes the ability to do something at the right time.

When conducting a research project, time pressure is the most important factor. Making partial deliveries, correcting intervals or meeting regulatory deadlines are phases of any research process.

Also in this case, "Time" is a way of signifying years of experience, trial and error, the development of one's own research and the arbitration of processes and results. In this way, the methodological understanding has been accessed in which the traditional scientistic understanding is transformed to achieve a simple [never easy] and systematized, logical and accessible way for Design researchers. 


\section{Theoretical Principles of the TIME Model}

According to the general methodology, it is essential to know the background that gives rise to the research because it is problematic and conflictive to start from illiteracy in relation to the subject to be studied. Ignorance generates ineptitude and by a domino effect, if the researcher is allowed to start in obscurantism, at some point the evidence will lead to a resounding fall of the project in any field of Design.

It is unavoidable to elaborate with the researchers a platform of universal methodological knowledge in order to incorporate a project in the totality of the epistemological bases. The first outline will be about the differences between general methodology and any particular methodology, (Gortari, 1983, p. 12) understanding in each case the links of the tripartite scheme: theory, method and technique.

It is essential to clarify the misnamed Research Methodology, which is actually the operational and logistical part of the general methodology, which is usually presented to laymen as the basis of research. When authors refer to qualitative or quantitative methodologies as resources to elaborate a research proposition (hypothesis), they are actually referring to statistical techniques and compilations, not methodological models. Tashakori and Teddie treat the qualitative-quantitative mixture as a "third methodological paradigm" which is not such. (2003, p.19).

In the same way, any researcher of Design and the designed will have to discern between the three great methodological models, which continue as real substantive paradigms of logical thinking. Systematization is important and, although there are notions that moving from the whole to the parts is a deduction and the reverse path leads to induction, one cannot do without the deepening of the deductive, inductive and dialectical methods in order to understand the critical paths of reasoning.

In this case, the purpose of the research is to reflect on what is designed or to generate knowledge about Design. In all situations, the researcher demonstrates his ability to link knowledge from intradisciplinary fields, interdisciplinary or transdiscipline ${ }^{1}$. In addition, any project poses epistemological conditions of study, comparison, analysis, criticism, comprehension or proposition, arguing consequently with a significant demand of logic.

For the understanding of the TIME model, the explanation of concepts and categories is essential. The concept arises from the need to define, describe, characterize, generalize, classify and understand specific terms whose concrete properties are grouped in the epistemological experience of the disciplines as common qualities due to their similarities and differences. Thus, a concept expands the meaning of diverse logical forms and, in this way, it is applied or designated to the varied objects, facts, processes and situations of a particular term. The concept refers to the act of understanding. (Fernández Rodríguez, 2006-2013)

A concept creates multiple relationships, unites words or, what is the same, links ideas and relates them to mental images and previous experiences. Concepts are the basis of cognitive structures.

Categories are the general concepts of a discipline, beyond which there is no other concept that groups or implies them, being the starting point for the deductive and dialectic construction of a theory.

\section{Dialectics of Design Research}

In the highest categories of Design knowledge are the philosophical ones, called universals, because they integrate cognitive psychology, epistemology and ontology. Universals are abstract entities from which particulars or concrete entities derive, for example from "being" derives "human being." These are the great bases of Philosophy: being, entity, essence, substance, domains that according to Ferrater Mora, interpreting Aristotle, are described in three spheres: as superhuman archetypes, as essence of things and as concepts through which we speak of things. They acquire meaning by establishing questions, abstractions, answers, concepts, relations and implications. (Ferrater Mora, 1951, pp. 652-657).

For the above, experience is a mode of knowledge where reason demands understanding and not only the reception of data and images. We know things according to what we are able to do. It is necessary to establish links between experience and concepts, then link together related concepts to concepts in chains of grouping.

The dialectic of research in Design is resolved according to the triad in which the concept, the mental image and the fusion of both or materialization, engender the solution to a questioning and cause a need for 
inquiry. It is the answer to what is going to be investigated and how is it going to be investigated? this dialectic is the result of knowledge itself.

The dialectical method applied to Design is a model based on a triad of concepts superficially called thesis, antithesis and synthesis. The sequence of these elements supposes an original proposition, a second moment of contrast and the extract that emerges from the two previous ones as the epitome of their confrontation. This method has variant fields that imply differences. Fichte, for example, subordinated the process to the antithesis by placing it after experience, which attracted numerous criticisms to his postulates. Hegel, considered the father of dialectics, proposed that the evolution of the method be projected in the synthesis as a result of the thesis and antithesis "a priori." Marx, in dialectical materialism constructs the method as the antithesis of the Hegelian model because it deciphers the material and pours it into abstractions or ideas. (Marx, 1974: xxiii-xxiv).

In the Hegelian system, which is the basis of this dissertation, the thesis is the original entity or idea, it is that from which one starts. Hegel called it the being or the idea. However, the idea as such is vague, diffuse, it is lost, it is only understood as an approach to what is. Research is required as a way of approaching the concept that is precise and specific.

The spirit has for us as its own presupposition the first absolute [...] the idea that has reached its being by itself, whose object and subject at the same time is the concept [...] the essence of the spirit. [...] To reveal, in the concept, is to create the world as its being, in which the spirit will be the affirmation and the truth [...] (Hegel, 2009, pp. 537-541).

The conceptualization of ideas requires a critical engagement with Design or the visual arts, as it is a sequence of dynamic phases that put reason before any subjectivity. Judgments and notions are here constructs of thought, of the clear conception of what has been focused and therefore knowledge.

The research of a discipline such as Design provides answers to numerous questions and allows epistemological assertiveness, formulates chains of cognition, discernment and directed intuition. It is the knowledge of the arts and Design. Ausubel points out that learning is meaningful when new studies can be related to previous knowledge. (Ausubel, 2009, p. 18) Intelligence is the resource for structuring cognitive states on non-arbitrary bases. It is here where conceptual warps and comprehension networks are confronted.

Antithesis is understood as the materialization of an idea in the totality of nature or in a given object of nature. It is a thing that must have a point of coincidence with the idea. Antithesis is conceived by Hegel as the world of antinomies "that is, the affirmation of two opposite propositions about the same object, in such a way that each of them can be affirmed with the same necessity." (Hegel, 1982, p. 31)

There is a misunderstanding that the antithesis is the opposite in the logical sense, that is to say, the antagonistic confronted, something incompatible. The antithesis is not the formal opposite, it is the estrangement, the exit of the idea from itself to reach objective concretion. It is the concretion, the representation or materialization of the idea.

For example, if the idea is a circle, the antithesis will have to define what the circle is like in a mental image; what is not, in this case, a square or a rectangle, is also discarded. It can be exemplified in this way, however, that if it is a question of expressivity, what is it? what is the concept of this or any other value? changes the epistemological panorama, it is the thought of the empirical world.

Finally, the synthesis is the fusion of thesis and antithesis, it is something different that must embrace both parts of the triad. It is the postulate that results from the concept and the mental image. Paul Rand stated that "without idea there is no Design", here an epistemological clarification is made: without concepts there is neither Design nor Art, and these arise from research and knowledge, not from visual or external appearance. This is when we speak of the result of the mediate knowledge that is formed between the concept and its materialization. This is what Hegel calls the "determined being" which is understood as the investigated and the reasoned. It seems a simple chain in which we find only three links, there is no such reductionism, the matter concerns more complex thinking which, while respecting subjectivity, reduces ambiguity. (Morin, 2018, pp. 32-36) 
In every research problem there are considerable returns to thesis, antithesis and synthesis, this is determined by a semantic and rhetorical spiral and by the encodings and qualities of the object of study: Design, designer or the designed.

\section{Epistemological Developments of the TIME Model}

The subject of any research on the possible trajectories of Design encompasses the constructs of orientation and education, with a focus on the formation of the personality, the work discipline and the processual or evolutionary dimension (Bausela, 2006, pp. 16-28). (Bausela, 2006, pp. 16-28) Likewise, taking Sanchiz's taxonomy (2009: 136) in the research work, conceptual, procedural and attitudinal learning are immersed in what Margolin (2010) understands as searches from Design to Design or for Design.

William Glasser's theory of choice (Choque, 2014) is incorporated to the above, according to which the researcher's actions must be directed as profitable moments in which learning by doing takes place. The guide are the levels of learning followed by numerous authors among which are Ausebel with his theory of meaningful learning, Montessori and her active method or Malaguzzi's methodology. Glasser's levels are: reading, listening, seeing and looking, seeing and hearing, speaking, writing and explaining. According to the author we learn $10 \%$ from what we read, $20 \%$ from what we hear, $30 \%$ from what we see, $50 \%$ from what we see and hear, $70 \%$ from what we discuss with others, $80 \%$ from what we do and $95 \%$ from what we explain or teach others. (Glasser, 1999).

Channeled research is a fundamental task, it allows the understanding of those phenomena that prevent researchers from completing a project that should have sufficient coherence and fluidity to enable them to close any cycle of inquiry with the relevant conditions. One of the worrisome effects is the quality of numerous explorations.

The reflection, observation and review of cases made it possible to identify that the generation of radical options distances Design researchers from the opportunity to approach the experience of elaborating a project in which it is demonstrated that they know the literature of the discipline, that they have the capacity to examine and infer and that they have mastered the terms of selective reading.

Design research is usually based on a sequence of trial and error experiences, since probabilities and research methodology are not a basic training requirement for designers who, in the best of cases, assume that disciplinary methodology is equivalent to research methodology channeled by praxis.

Another pattern of Design research matters for the experience it entails, since rigor, the ability to organize sources or the effort to systematize thought is always an opportunity to acquire knowledge.

Moreover, exploration represents the singular juncture to explore interdisciplinary knowledge by learning the infinite possible relationships from any epistemological niche. The method as an abstract conceptual process is meaningless if it is not expressed through language and applied practically for the transformation of reality, therefore, if it is considered that any search task requires the obligatory good use of the semantic field, it is necessary to add the advantage and opportunity to externalize in written form the thoughts of its creator, in it the acquired knowledge is manifested.

Research is a process that, by means of procedures considered valid, reflects on an object of study, increasing the domain it has, it is aimed at elucidating that which a community, in this case teachers, scholars, professionals or critics of Design, considers unresolved or partially addressed. That is why lines of research are defined, which invite the researcher to link up with a problem in the field of study identified as a priority.

The lines of research (Suing, 2008) are defined on the basis of intra, multi, inter or transdisciplinary relationships. They are usually areas of interest, thematic axes or research perspectives and are most commonly specified in fields of knowledge, curricula, academic publications, research group projects or researcher's work nuclei.

Currently, the term "state of the art" is used with misconception, which demonstrates an enormous ignorance on the part of those who imitated it, since it includes a term that alludes to one of the great circumscriptions of knowledge. Art is a vast and complex concept that derives in numerous disciplines, to use this lexical unit to refer to the exposition of the circumstance, condition, nature or situation of a subject, is a linguistic and conceptual aberration in areas foreign to Art. The Dictionary of the Royal Spanish 
Academy describes: The status of the art, a reprehensible calque of the English status of the art: "You will have the inestimable opportunity to see there [...] the most advanced developments, the status of the art of our various technologies" (Abc [Esp.] 12.7.96). In Spanish, it is recommended to replace it by the expressions estado or situación actual, últimos avances or estado de la cuestión, as appropriate.

Of the elements that comprise the development of a research project, the choice of the topic is undoubtedly the most difficult because it implies the definition of a specific object and the determination of the type of intellectual work required for this task: analysis, contrast, comparison, definition, description, critique, demonstration, synthesis or evaluation. This stage should result in the choice of a subject of study which is linked to the lines of institutional or disciplinary research in the best terms of feasibility.

This implies the exploration and definition of the object of study with the precision of the factors that determine it, the review of its admissibility and the answer to the questions about what subject is to be worked on, what is the area of knowledge that is most mastered or known and what is the subject, within the area of knowledge, that is of most interest to the researcher...

The object of study should be expressed in as few words as possible; one is optimal. Eli de Gortari (Gortari, 1983, pp. 40-41) recommends the reduction of the object of study to its core meaning, placing it within the established system of knowledge, practicing the logical analysis of the constants or dependent and non-dependent variables that contain its possible epistemological links, including both the known ones and those that at that moment may be perceived as possible. From a constructivist perspective, our presentation is based on the assumption that research is a way of constructing a representation of a phenomenon of interest [...] the phenomenon of interest is the object of study. (Barriga and Henríquez, 2003, p. 79).

Research must focus on something recognizable and defined that is also identified as such by the community of Design researchers, an object, says Umberto Eco, with the possibility of being an "object of inquiry", susceptible of verbal discourse. (Eco, 2009, p. 45).

Scientific research emphasizes the transparent and criticizability nature of the way of constructing the object, however, let us remember that Design is not a scientific discipline, therefore, let us not seek to subject it to inadmissible scientism. The phenomenon of interest is the object of study, it is what we want to perceive, analyze, understand, decipher and explain; the way of constructing its representation is the research process, with all its epistemological, theoretical, methodical and technical complexity.

Following the process built so far, the procedure pursues Bunge's vision of externalizing the problem to be investigated, documenting and defining it, imagining a possible answer to it or a proposition about... elucidating the consequences. (Sierra, 1989, p. 42)

Subject to feasibility factors, preliminary research is the construction of the conceptualization. It is the first epistemological or cognitive precision movement. It consists of locating and reviewing sources of bibliographic documentation to examine the basic concepts from what is already known, to analyze, relate and select the contents considered pertinent to the problem and to classify them in advance.

Once the basic concepts have been resolved, the researcher will review all the possible secondary concepts that each basic concept may lead to and will decide which ones are pertinent to work on as possible research contents.

This work, which seems elementary, is not, it is something simple, which is not synonymous with easy; correct thinking would speak of the singularity of research. The aforementioned is supported by the idea of entropy of knowledge, (Rifkin, 1981, pp. 145-149) according to which, first one has spatio-temporal boundaries, then uncertainty before a set of ideas, (Schwarz, 2014, p. 54) of which, only some are chosen, this is an overall condition of the causal structure of the research project.

The basic and secondary concepts are the most important requirement of the research order, they are the strong ideas and are equated with what Stephen Hawkings calls the global hyperbolicity: an open, but bounded set, there is no closed figure. (Hawkings \& Penrose, 2013, pp. 13-22) Concepts are epistemologically conjugate points. 
At this stage, in addition to relating the object of study with basic and secondary concepts, the feasible links for the subsequent conceptual structure are established. Thus, the researcher will be prepared to build the conceptual scaffolding with critical thinking, deploying his ability to make decisions and solve the project's path.

To transform the concepts into a structure, the researcher requires introspection which aims, as Alex Osborn states, to break the usual boundaries of thought in order to elaborate the materialization of concepts as statements without leaving isolated terms or elaborate value judgments. (Osborn, 1960, pp. 39-42)

The organization is the basis for the research scheme and is part of the second epistemological movement. The outline is the guide for carrying out the research process and the backbone of the project.

From this index, the open conceptual organization with limited hyperbolicity is configured. This disposition is not considered closed, it always has margin and in fact there are modifications in it during the course of the project.

To understand the logic of a scheme there are models or symbolic representations, among the best known are those of the French plan, Mazeaud's, Hubbell's (normative, historical and experimental) and Baena Paz's, among others.

To start any research protocol from the scheme is a task that flows naturally and expeditiously. The title of the research is determined based on the basic concepts considering as limiting factors: temporality, spatiality, classification, quality, quantity, conceptualization, disciplinarity or transcendence.

This moment culminates with the search and closing of the research corpus that integrates all the indispensable sources of knowledge for the coverage of the points of the research outline. During this period the most important thing is to understand that the decisions made regarding the sources of information and knowledge will be decisive for the course of the project. This implies responsibility because it has repercussions on the quality of the work, the epistemological characteristics that the researcher will impose and, as a whole, the expectations of completion. The resources to obtain knowledge always mark the course and the end.

In the third epistemological movement, the steps are elementary and direct, it is the sequence of materialization around knowledge: read, select, register, organize and shape. It is expressed with comprehensibility and in a few words, however, it is a stage that requires order, rigor, discipline and strict time management.

The above is a spiral sequence, with dialectical moments, in which the researcher does not stop his work. Interrupting the continuity leads to one of the great mistakes in research, such as not moving forward or returning to routine vices.

When the researcher finishes all the sections of the work, he proceeds to the assembly stage. This refers to the union and articulation by instrumenting corrections. The researcher demonstrates at this stage the diligence and thoroughness he has acquired with the knowledge, and will demand from himself an unavoidable commitment in the search for sequence, coherence, correspondence, cohesion and unity. When this has been carried out judiciously and sensibly, the researcher will have the first complete written version of his project.

\section{TIME Model Efficiency Keys}

When research progresses, particularly in the cycles of reading, filing, organizing and writing fragments, the tasks are hindered if the keys to efficiency are not taken into account. The first refers to the principles of rigor with which the issues are addressed.

Discipline points to the organization of time and work rules. It is necessary to establish priorities and coordinate what in each case is the right way.

As a great limitation in this topic, it is unappealable the preference that must be given to good health, to family and emotional ties or to the tasks of a job. If this, which is a priority, is not under control, the researcher will not be in a position to take on the project.

If there is a safe and reliable environment, discipline is possible. The exercise is self-management, that

is, each person decides the movements and exercises to be carried out in order to persevere with determination in the research task. 
How to allocate time will be the core and essence of decision making, assuming that schedules are required for: attending libraries or documentation centers, making online consultations, writing worksheets, reading, reflecting or writing.

Two hours a day or six hours during a single day make no difference as long as the interested party is willing to comply with the resolutions. The ability to follow one's own instructions is learned by starting with the preliminary research, where the seed of the discipline is sown and germinates, in which the researcher forges a logical and dialectical system of doing in such a way that it translates into a methodical model.

To delineate lapses and actions, one must first carry out the geography of chronophagy itself (a neologism that comes from the root khronos meaning time and phagein meaning to eat), that is, the set of objects, persons, facts or circumstances that are eaten in a person's time. Chronophages are divided into eludibles (eventualities that can be postponed or cancelled) and inescapable (forced, necessary and unavoidable elements). The factors of discipline and chronophagia are directly proportional, since by increasing the former, the latter are fragmented and diluted or take on their rightful dimension in the existence of the individual.

\section{CONCLUSIONS}

The so-called research problem in Design consists in proposing to say something not yet said about the object of study or to review what has already been said from a different point of view. To do so, it is essential to look for at least one concept that is related to the object of study and that satisfies the researcher's concerns. It is necessary to answer the questions: what is it that one wants to know? what is the epistemological gap to be covered? or what is the discussion that this issue implies? this will allow its adequate formulation and the possibility of fulfilling the task that has been proposed.

The indisputable answer and the one that gives the best results is to state the object of study as what one wants to know. From a constructivist perspective, this somewhat obvious formulation is based on the assumption that research is a way of constructing a representation of a phenomenon of interest. Discipline is the contract with oneself to direct individual drives in favor of reason, performance and professional efficiency as a researcher.

From this perspective, it is evident that theory, method and technique integrate the elements of all research practice and must be understood by their mutual relations and not independently. The general methodology determines the epistemological universe, the analysis of the foundations of the theory of knowledge and implies the approach to the general methodological models and the conceptual assumptions on which they rest. (Vilchis, 2014, pp. 13-23).

\section{ACKNOWLEDGEMENT}

Translated \& edited by American Publishing Services (https://americanpublishingservices.com/).

\section{REFERENCES}

Ausubel, D.P., Novak, J.D., Hanesian, H., Pineda, M.S., \& Botero, M. (2009). Psicología Educativa un punto de vista cognoscitivo. México: Trillas.

Barriga, O., \& Henríquez, G. (2003). La presentación del Objeto de Estudio. Reflexiones desde la práctica docente. Cinta Moebio, (17), 77-85. Retrieved from

https://www.moebio.uchile.cl/17/barriga.html

Bausela Herreras, E. (2006). Áreas, contextos y modelos de orientación en intervención Psicopedagógica. Revista Diálogos Educativos, 6(12), 16-28. Retrieved from

https://dialnet.unirioja.es/servlet/articulo? codigo $=2473883$ 
Choque, J.W. (2014). Aproximación a la Teoría de la Elección. Revista de Investigación Scientia, (3), 1. Retrieved from http://www.revistasbolivianas.org.bo/scielo.php?pid=S2313-

02292014000100003\&script $=$ sci_arttext

de Gortari, E. (1983). Metodología general y métodos especiales. Barcelona: Océano.

Eco, U. (1995). Semiótica y Filosofía del Lenguaje. Barcelona: Lumen.

Eco, U. (2017). Cómo se hace una tesis. España: Gedisa.

Fernández Rodríguez, J.L. (2013). Concepto formal y concepto objetivo. In F. Fernández Labastida \&

J.A. Mercado (Eds.), Philosophica: Enciclopedia filosófica online. Retrieved from

https://www.philosophica.info/voces/concepto_formal_objetivo/Concepto_Formal_Objetivo.html

Ferrater Mora, J. (1951). Diccionario de Filosofía. Tomo II. Buenos Aires: Editorial Sudamericana.

Glasser, W. (1999). la Teoría de Elección. Una nueva psicología de la libertad personal. Barcelona: Paidós.

Hawkings, S., \& Penrose, R. (2013). La naturaleza del espacio y del tiempo. España: Penguin Random House Grupo Editorial.

Hegel, G.W. (1982). Ciencia de la Lógica. México: Solar.

Hegel, G.W. (2009). Fenomenología del Espiritu. Valencia: PreTextos.

Kuhn, T. (1971). La estructura de las revoluciones científicas. México: FCE.

Maldonado, T. (1998). Crítica de la razón informática. Barcelona: Paidós.

Margolin, V. (2010). Doctoral Education in Design: Problems and Prospects. Design Issues, 26(3), 70 78. USA: MIT. Retrieved from https://watermark.silverchair.com/desi_a_00031.pdf

Marx, C. (1974). El Capital (Volumen I). México: FCE.

Monereo Font, C. (Coord.). (2002). Estrategias de aprendizaje. Madrid: Universitat Oberta de Catalunya (UOC).

Morin, E. (2018). Introducción al pensamiento complejo. Barcelona: Gedisa.

Moursund, D. (1997). Foundations for The Road Ahead: Project-based learning and information technologies. Washington, DC: National Foundation for the Improvement of Education.

Moursund, D.G. (2002). Project-Based Learning Using Information Technology. USA: International Society for Technology in Education.

Osborn, A.F. (1960). Imaginación Aplicada. Madrid: Velflex.

Rifkin, J. (1981). Entropy. A New World View. New York: Bantam Books.

Sanchiz Ruiz, M.L. (2009). Modelos de orientación e intervención psicopedagógica. España: Universitat Jaume.

Schwarz Díaz, M.G. (2014) Una medida de la incertidumbre basada en la entropía para cuantificar el impacto de la pérdida de información de los sistemas de gestión. Revista Paideia XXI, 4(5), 4656. Lima: Universidad Ricardo Palma. Retrieved from http://revistas.urp.edu.pe/index.php/Paideia/article/view/907

Sierra Bravo, R. (1989). Técnicas de investigación social. Madrid: Paraninfo.

Suing, A. (2008). Definición de las líneas de investigación. Ecuador: Universidad Técnica Particular de Loja. Retrieved from https://es.slideshare.net/abelsuing/definicin-de-las-lneas-de-investigacin

Taborga, H. (1982). Cómo hacer una tesis. México: Grijalbo.

Tashakori, A., \& Teddie, C. (2003). Handbook of Mixed Methods in Social \& Behavioral Research. USA: Thousand Oaks, SAGE.

Vilchis Esquivel, L.C. (2014). Metodología de la Investigación. Fundamentos Teóricos. México: Designio. 